\title{
9
}

\section{Succeeding and failing in crafting environment policy: Can public policy theories help?}

Kathleen Mackie

\section{Introduction}

Mainstream Western accounts of the policymaking process often bear little resemblance to the realities of those who 'accomplish' the actual policy work on a daily basis. (Williams 2010, p. 195)

It is worth talking to academics and others to understand policy, because people like me can't explain why we did what we did. We just did it. A lot of it is understanding the craft. You think everyone gets it. But it is amazing how many people don't. (Interview with a policy practitioner with 30 years experience in federal environment policy, as cited in Mackie 2014, p. 19).

Will training public servants in policy theory help to improve their capabilities and thereby contribute to achieving better policy outcomes? This question is increasingly important for environment policy, given that climatic and environmental threats to human survivability and biodiversity continue to escalate. If policy theorists can strengthen the capacity of policy officials to deliver innovative and effective policy advice and solutions, the benefits would be valuable. Indicators that we no longer have the luxury of lengthy ruminations over policy theory and policy 
practice can be found in two examples. First, the 2018 Intergovernmental Panel on Climate Change (IPCC) report highlights the truncated time frame available to avoid the most damaging impacts of climate change, and concludes that:

If the global temperature rises by $1.5^{\circ} \mathrm{C}$, humans will face unprecedented climate-related risks and weather events. We are on track for a $3-4^{\circ} \mathrm{C}$ temperature rise. To meet a goal of $1.5^{\circ} \mathrm{C}$ warming, this demands immediately cutting the planet's emissions to $45 \%$ below 2010 levels by 2030 . (IPCC 2018)

Such action would require unprecedented global agreement to policy actions.

Second, in the Australian context, the graphic failure of the MurrayDarling Basin governance arrangements to avoid serious damage to that essential river system over many decades underscores the need to improve environment and natural resource management policy (Government of South Australia 2019). Phillip Glyde (2019, p. 19), chief executive of the Murray-Darling Basin Authority, recently argued that the basin plan is science-based. However, it has clearly failed in its implementation and in ensuring all the stakeholders play a constructive role. Successful 'policy' requires more than transparency and an evidence base.

Practitioners and policy theorists share a common desire to provide effective support for those new to the work of policy, and those who need to craft good policy in the context of significant and changing political and economic constraints. This chapter offers a practice-based perspective on how policy theories and frameworks can assist policy analysts to deliver good policy advice to ministers for their consideration and decision.

Academics in the public policy field are acutely aware of the disconnect between policy theory and policy practice. They know that many policy officials learn their craft on-the-job (Allen \& Wanna 2016; Mercer this volume, Chapter 3). For my own part, I was trained in economics and geography and then found myself at the policy coalface with no background in policy theory, politics or political science. I kept quiet and watched, while continuing to make errors. In my early years, the machinations and manoeuvrings of senior policy officers higher up the Australian Public Service (APS) ladder were not transparent or explained. It was a matter of learning on-the-job as best as one could in a world in which policy development strategies were not made explicit, failures were not examined and policy successes were not mined for shared lessons. 
The ways in which policy officials undertake and orchestrate their roles in the policy process are generally not revealed in the policy literature in a clear or systematic way that would encourage emulation (notable exceptions include studies on street-level bureaucrats and policy entrepreneurs). There is still a dearth of studies informed by a practitioner or 'insider' perspective. For example, Jarvie (personal communication, November 2013), in her work on policy learning, found that there has been surprisingly little systematic work in Australia on how public servants behave in complex policy environments. Samnakay (2017, p. 106) observed that 'the process of how national strategic policies are developed and implemented in Australia is unclear, and largely unattended in the literature'. Moreover, few studies have sought to identify the cues that policy officials pay attention to in assessing whether or not an environment policy is likely to succeed.

This chapter argues that policy theorists would do well to investigate exactly how policy officials go about their work. ${ }^{1}$ Such research is difficult because, under the APS Code of Conduct and security requirements, public servants are significantly constrained in their right to divulge the inner workings of policymaking. Theorists such as Colebatch, Hoppe and Noordegraff (2010) and Williams (2010) have acknowledged that their understanding of policymaking has been held back by difficulties in documenting the actual experiences of policy officials (Mackie 2014, p. 9). As Williams (2010) noted, academics are acutely aware of their limited access to the core artefacts that move policy forwardthe internal documents, people and processes of government. In her view, the academic is on the outside looking in. Yet, accessing insider perspectives, however difficult, is necessary if policy theory is to offer practitioners the tools, frameworks and understandings that underpin the craft of policymaking.

1 The findings in this chapter are drawn from doctoral research I conducted in 2011-14 into why some federal environment policies in Australia fail and others succeed (Mackie 2014, 2016). The research documented how federal environment policy officials avoided failure and pursued success over the period 1993 to 2013. Of relevance here, the research demonstrated that policy officials drew on their experience, instincts and intuition rather than the array of policy theories and frameworks in the public policy literature. 


\section{Changing policy dynamics}

Questions relating to how policy theory can inform and support the work of policy officials are pertinent across all policy areas and jurisdictions. My doctoral research focused on the area of federal environment policy. Federal engagement in environmental policy is fairly recent. From a relatively small agency in 1971, a fledgling Department of the Environment grew during the 1980s. The 1996 Howard government gave its Minister for the Environment, Senator Robert Hill, a place in Cabinet for the first time. Hill proved to be a highly effective minister. He brokered the landmark Environment Protection and Biodiversity Conservation Act 1999; established the Natural Heritage Trust; improved Australia's fuel quality, thereby generating air quality and emission reduction benefits; and set in train Australia's national oceans policy agenda.

As it evolved over the next three decades, the department nurtured a distinctive generation of environment policy officials who were in the main passionate about protecting the environment but savvy enough to stay within Westminster boundaries. By contrast, over the last decade, the scope for creative environment policymaking appears much diminished, with a greatly reduced budget, increasing politicisation of the federal bureaucracy and climate change policy, and a series of less effective environment ministers than previously.

\section{Trigger for the research}

My research interests were triggered by the political and policy chaos arising from the then Department of the Environment's Home Insulation Program. Under the Rudd government, the program had aimed to insulate 2.7 million homes from its commencement in February 2009; however, the program was abruptly terminated in February 2010 after four young installers employed by private contractors under the program died. The Home Insulation Program was one of 12 environmental policies I researched. In October 2009, I was asked to assist to rebuild trust between Minister Peter Garrett and the Home Insulation Branch. After my first day, I came to the strong view that the program ought to be terminated. On my second day, 14 October 2009, the first death occurred, that of Matthew Fuller. One of the environment policy officials who crafted the initial policy proposal to fund home insulation as an energy efficiency measure told me that when she heard that $\$ 2.7$ billion 
had been approved as a part of Rudd's stimulus package, she knew the program would fail and she quietly moved jobs. That clear prediction of failure triggered my interest in the policymaking process.

\section{How to access the insider view}

Accessing insider knowledge and experiences of how policy gets made requires a trusting relationship between the researcher and interviewee. I was able to interview the officials who had a core role in making policy over 20 years from 1993 to 2013. The interviews included all five secretaries of the department and the majority (nine) of the deputy secretaries from 1993 to September 2013. This coverage ensured the inclusion of policy officials who had access to ministers and their offices and were accountable for the implementation of Cabinet policy decisions.

All the policy officials who were invited to participate in the study agreed to be interviewed. This high acceptance rate may be explained by official support for the study, anonymity, a high level of interest in the topic and the fact that the researcher, as a former public servant, was known to the participants. All interviewees were aware of the support of the departmental secretary and board of management. Secretary of the Commonwealth Department of the Environment Dr Paul Grimes noted that my study had the support of the departmental management board, that respondents would not be asked to disclose any confidential information and that their anonymity was assured. That the study had ethics approval from the University of New South Wales, and that responses were treated confidentially and reported anonymously, provided further comfort to participants. Finally, all the interviewees had worked with me in a budget, corporate, program or policy capacity, or while in a central agency as a manager, subordinate or colleague. Taken together, these factors engendered a high level of trust and, thus, a willingness to talk openly about experiences of policymaking.

Interviewees were selected who had close exposure to, and could therefore comment on, the success or failure of six biodiversity and six energy/solar policies and programs (see Table 9.1). The interview canvassed which environmental policies (including but not restricted to the 12) had been successful, whether it was possible to predict success and what drove success or failure. By the 51 st interview, there was a sense of convergence in the responses, albeit with a spread of views about particular policies. The sample comprised 31 senior executive service policy officers, and 
20 executive level 1 or 2 officers. Over half the interviewees had more than 15 years experience in environmental policy. Nearly three-quarters had experience in Cabinet, budget or ministerial processes.

The interviewees considered the art of policymaking to be intuitive, perfected through a mix of policy nous, judgement and experience. They were highly qualified in areas such as law, economics and natural resource management, but few held formal qualifications in public policy. How they went about policy was, for the most part, learnt on-the-job, by observing or by osmosis. Notably, most interviewees struggled to define policy; this suggests an instinctual and experience-based approach rather than a theoretical approach. The one interviewee who was able to provide a ready definition had completed a masters of public policy. Most took time to think through how they would define policy (Mackie 2014, pp. 111-15).

\section{Insights from the policy theory literature}

As preparation for the interviews, I spent a year reading literature on public policy. I was keen to know whether any of the theories of public policy offered compelling explanations as to why policy failures occurred and how to avoid them. To my frustration, I found that little resonated with me. There were some great turns of phrase such as 'muddling through' (Lindblom 1959) and Cohen et al.'s 'garbage can' model (as cited in Dryzek 1983), but there was no coherent framework of policymaking that I could draw on to explore questions of what drives environment policy success and failure.

Kingdon's seminal 1984 work on agenda-setting struck a chord with me. Kingdon (2003, pp. 231-2) was able to uncover much about the intent, motivations and strategies of government officials and thus generate groundbreaking theory on agenda-setting through his in-depth interviews with United States government officials (Mackie 2014, p. 60). I liked the way Kingdon's three streams - problem (the policy issue), policies (the instruments and ideas) and politics (public opinion, stage of electoral cycle, degree of opposition) - could run in parallel, and that the policy entrepreneur, which could be a government official or lobbyist or other player outside the bureaucracy, could encounter considerable doses of 'messiness, accident, fortuitous connections and dumb luck' (Kingdon, 2011, p. 206; Mercer this volume, Chapter 3). 
My interviewees shared some wonderful stories about the shadowy practice of how policy is made-sometimes serendipitously. For example, in 1999, as part of GST negotiations, Prime Minister John Howard misheard a statement to the leader of the Australian Democrats by his treasurer, Peter Costello. Costello stated: 'I'll give Meg Lees \$400,000 for an environment package.' However, Howard heard $\$ 400$ million (Mackie 2014, pp. 175-6). As a result, the Department of the Environment had an enormous windfall in the budget that year and the $\$ 400$ million funded many environmental measures. Costello confirmed the veracity of this story of 'dumb luck'. This story raises the question: how does the policy theorist accommodate such seemingly random occurrences? Kingdon listened deeply to policy officials and, in doing so, was able to uncover much about their intent, motivations and strategies. He also revealed the value of interviews in a trusting relationship as a method of understanding policymaking. Yet, overall, I found no theory or set of theories that unpacked my experiences of policymaking in a way that meant success could be replicated and failure avoided.

\section{A framework to assess policy success and failure}

Marsh and McConnell (2010) provide a useful framework for analysing whether policy episodes can be categorised as success or failure. They measure success across three dimensions:

1. Process: how did the policy arise and what was its level of support?

2. Programmatic: was it implemented as per its stated objectives?

3. Political: was it popular with the electorate and therefore with politicians?

Marsh and McConnell's framework provided a coherent rubric to assess the 12 policies along a success-failure continuum to crosscheck what the interviewees were saying. Interviewee ratings of which policies were successful, had mixed outcomes or failed were compared to ratings I derived by applying Marsh and McConnell's framework (Mackie 2014). Table 9.1 sets out the interviewee assessments of the 12 policies grouped by Marsh and McConnell's framework (Mackie 2014, p. 108, 2018, p. 59). 
Table 9.1. Targeted federal environmental policies and programs 19932013. Success-failure per Marsh and McConnell framework vs successfailure per interviewees.

\begin{tabular}{|l|c|c|}
\hline \multirow{2}{*}{ Environmental policy or program } & \multicolumn{2}{|c|}{$\begin{array}{c}\text { Interviewees' success/ } \\
\text { failure nominations }\end{array}$} \\
\cline { 2 - 3 } Success & Failure \\
\hline Rated towards success under Marsh and McConnel|(a) & $23^{(\text {(b) }}$ & 0 \\
\hline Working on Country & 9 & 0 \\
\hline Fuel Quality Standards Act 2000 & 9 & 5 \\
\hline Rated mixed outcomes under Marsh and McConnell(a) & 16 & 5 \\
\hline Natural Heritage Trust & 11 & 9 \\
\hline Regional Forest Agreements & 11 & 3 \\
\hline $\begin{array}{l}\text { Environment Protection and Biodiversity Conservation } \\
\text { Act 1999 }\end{array}$ & 5 & 6 \\
\hline Marine Protected Areas & & \\
\hline Caring for Our Country & 5 & 18 \\
\hline Rated towards failure under Marsh and McConnell(a) & 0 & 8 \\
\hline Home Insulation Program & 0 & 3 \\
\hline Green Loans Program & 0 & 3 \\
\hline Solar Homes and Communities Plan & 0 & 3 \\
\hline Solar Hot Water Rebate Program & & \\
\hline National Solar Schools Program & & \\
\hline
\end{tabular}

(a) Rated 'towards success' means broadly successful on all three of Marsh and McConnell's dimensions (i.e. process, programmatic and political); 'mixed outcomes' means neither outstandingly successful nor unsuccessful on any one dimension but no major failings; 'towards failure' means broadly failed across all three dimensions.

(b) The interviewee nominations in each row add up to less than 51, as interviewees restricted such nominations to programs they had direct experience or some knowledge of.

Marsh and McConnell's framework provided a way of reality checking the interviewees' subjective assessments of policy success along structured process, program and political dimensions. The interviewees rated the Indigenous ranger Working on Country program (which provided award wages to Indigenous people to care for cultural and natural values on Indigenous tenure on behalf of all Australians) and National Fuel Quality Standards (which led to improved air quality, greenhouse emission and health outcomes) as notable successes. The Home Insulation Program and associated smaller Green Loans Program (which aimed to provide interest free loans to assist homeowners to invest in energy efficiency measures) were rated as absolute failures. While a few dissenters considered Home Insulation successful, a slew of public inquiries begged to differ 
(Australian National Audit Office 2010; Australian Royal Commission into the Home Insulation Program 2014; Commonwealth of Australia 2010; Hawke 2010).

Interviewees had a strong sense of whether or not a policy was going to succeed based on a range of indicators. Among predictive factors in the policy literature, they validated the importance of engaging with stakeholders, having clear objectives and knowing the evidence base. In the context of environment policy, they played down factors such as adequate resources, nature of the policy origins and clear policy design.

Respondents emphasised the importance of the policy mandate, especially in the hands of a capable minister. Additionally, policy 'agency'-legitimate but incisive interventions by officials to get a result for the good of the environment-was cited as a key to success. Examples of this positive agency were adding a land-clearing moratorium into Commonwealthstate agreements; invoking clauses of the Environment Protection Act to unlock marine protection policy; and paying Indigenous people fair wages to maintain natural and cultural values on Indigenous lands (Mackie 2014, pp. 191-204). Conversely, poor outcomes in Home Insulation and Green Loans were attributed to a distinct lack of agency. In the Home Insulation Program, for example, sterile briefings to the minister on critical safety and fraud issues were represented as a kind of 'agency by omission'. One specific example of this was highlighted by the 2014 Royal Commission into the Home Insulation Program, in which a senior executive failed to attach the risk register to a critical April 2009 brief to Minister Garrett (Hawke 2010, p. 32; Mackie 2014, p. 208).

\section{Agency of officials as a key driver of successful policy}

Westminster conventions decree that officials advise and ministers decide. Ministers and governments rely on the discretion of policy officers. Politicians, their advisers and departmental senior executives need to be able to fully trust the officials providing advice and policy solutions. The hidden but vital role of officials, as they try to steer policy towards success, is difficult to see in practice or express in theory. The in-depth interviews with environment policy officials revealed that their deliberate manoeuvrings to get policies onto the minister's agenda, and to pursue policies though to success, were a key factor in whether environment policies failed or succeeded. 
The interviewees revealed that they rarely drew on policy theory, models or frameworks to inform their policy work. Surprisingly, experienced and adept policy officers struggled to define 'policy'; they considered policy work instinctual-it was in their DNA. Sure, they were aware of the policy cycle and relied on it to keep an eye on the process steps needed to deliver a policy result. Some had even been trained in the concept (Mackie 2014, pp. 115-17). But, in the main, they learnt on-the-job. That learning ranged from a patient watchfulness for the opening of a 'policy window' to the masterminding of clever shortcuts and alternate routes to overcome the political, economic and resource barriers to delivering good policy.

A former departmental secretary interviewed for this study concluded that, although officials generally understood what constituted good public policy, responsibility for policy failure could be sheeted back to officials expending too much time and effort on formulating the policy framework, and not enough on crafting a policy narrative that dovetailed the government's political priorities with the interests of the primary stakeholders, enabling the politician to understand and sell the policy to the electorate. Climate change policy was his prime example of this fundamental failure to bring the political realm along by developing a policy narrative elegant and simple enough for the electorate to understand and accept. The interviewee stated:

I think we spent at that time far too much time in formulating the policy framework for climate change and not on the communications and political leadership framework. On the whole, I would have to say that climate change was perhaps the most disappointing failure of mine. I worked on it for eight or nine years. (as cited in Mackie 2014, p. 229)

Through listening to the insider experience of policy success (and failure), this study generated clues on how to think about the instrumental role of officials in policy. That is not to say the interviewees were overplaying their role. They were mindful of the role and power of the federal environment minister and Cabinet, and circumspect about their reach as bureaucrats. A mid-level official, highly regarded by ministers and the departmental executive, and possessing extensive Cabinet and Department of Prime Minister and Cabinet experience, volunteered that:

I can think of only one example of a policy process where I was able to have a role that made a difference. It was in the water process. It was the only single direct difference I made on environment policy the whole time I was working for the government. It was 
when I was asked by the Prime Minister's Office to brief the PM on a demand by irrigators to change the water policy that was before Cabinet. I quickly orally briefed the Prime Minister's advisor. I briefed him to tell the PM not to agree to a water allocation for rice irrigators in a particular year when there was insufficient water, as to give them an allocation would have set a precedent. I knew a lot about the issue and I had all the facts and figures at hand and I was emphatic. My case was irrefutable. It was a simple story and a well-defined problem. I wrote a note for file. The irrigators were expecting the PM to agree to their demands. But he didn't. He took my advice. (as cited in Mackie 2014, p. 214)

As this quotation demonstrates, opportunities to pursue agency are scarce yet vitally important. Indeed, my analysis of the experiences of 51 interviewees suggests that the notion of official as 'policy agent' is underplayed in the theoretical literature. This is largely because of the mantra that 'politicians decide and officials implement'.

\section{Implications for policy theory}

As already stated, my research revealed that a high level of agency by officials is a key to understanding policy success and failure. This suggests that academics would be well served in their theory development if they made concerted efforts to access the insider world of policy officials. For policy theory to gain greater relevance, more focus on the tactical manner in which officials pursue policy agendas is needed. The findings remind policy practitioners that their skills and interventions (or failure to intervene) are vital in the policy process, notwithstanding contemporary pressures towards politicisation and marginalisation of the public service.

\section{Legitimacy of officials' agency in policymaking processes}

In regard to the legitimacy of their behaviour, interviewees were able to distinguish between 'understanding the politics' and 'acting politically', and between being apolitical and being politically savvy. One interviewee, for example, described the need to have a sense of how the politics of a policy issue might play out, while at the same time taking care to avoid being a part of the political landscape or being aligned with stakeholder positions. 
The department secretaries interviewed for this project were comfortable with their actions in terms of taking a strong agency role in pursuing policy outcomes. They saw it as a necessary part of providing full advice to their minister. This behaviour of prudent autonomous policy is not necessarily inconsistent with the Westminster system of government. However, such behaviour is not identified to any significant degree in the policy literature. Colebatch (2006, p. 3), one of Australia's leading policy theorists, has argued that the well-recognised account of the Westminster system may not be consistent with the experience of policy workers.

This dissonance between the rhetoric of the Westminster tradition and the actual experience of policymaking is beginning to be acknowledged in analyses of, and official documents on, policy administration in Australia. Stephen Sedgwick, former head of the Australian Public Service Commission, observed a softening in approach to the convention that 'government decides' and 'officials implement' (Towell 2013). Sedgwick suggested that past approaches to policy development have been weak on the concept of 'strategic foresight capability'. This concept parallels the notion of agency. Sedgwick argued that some ministers and some governments are interested in a forward-looking public service that is more actively engaged in setting the strategic policy agenda and, therefore, can provide more than simple responsiveness to the agenda of the government of the day (Towell 2013).

Banks (2013, p. 4), when head of the Australia and New Zealand School of Government, reinforced the importance of policy officials finding the right balance in respecting the policy decisions of government and doing a 'solid job in advising and informing government policy decisions'. He saw that balance as important in addressing the mounting number of policy failures in Australian federal policy, such as the carbon and mining taxes, the National Broadband Network and key strands of immigration policy. Banks (2013, p. 9) argued that policy ideas need to be 'tested and contested before implementation-within the bureaucracy, the community, the Cabinet room and, ultimately, within the Parliament'.

Contrary to the perception of Canberra public servants (bureaucrats) as self-serving, the interviewees in this study revealed a high level of commitment to civic service. Most expressed a commitment to delivering meaningful and measurable environment policy outcomes for the public good through a high level of inventiveness and persistence. Collectively, 
the interviewees were public spirited and knowledgeable. The following statement by an interviewee is representative of the sentiments of all interviewees on their role as players in the policy process:

\begin{abstract}
Everyone pursues particular policy agendas to an extent. Everyone is a policy actor in a sense and each of us thinks that we are doing it in the public interest. And we just have to keep each other honest in that regard and remind each other of that. I don't see 'actor' as a pejorative term. Each of us has views. We are not value neutral. We all have views. Part of my motivation for working for the Commonwealth is I want to produce good public policy outcomes and they don't always align with what the Government wants. But ultimately I am accountable to my seniors here and to the Government and to the Minister actually, and through him to the Parliament. (as cited in Mackie 2014, p. 223)
\end{abstract}

In summary, although the policy officials interviewed for this study revealed a surprisingly high degree of agency, their intent in doing so was to deliver good public policy. Many of the interviewees had elected to work in the Department of the Environment because the portfolio function of protecting the environment aligned with their personal values. Instances of leaking confidential documents (e.g. as occurred in the Regional Forest Agreements process) or of improper behaviour (e.g. as exhibited by the rogue executive level 2 in the Green Loans Program) underscore how agency behaviour can be highly inappropriate, to the extent of contravening the APS Code of Conduct and the Public Service Act 1999 (Mackie 2014, p. 223). High-profile examples are evident in other policy areas, such as the Australian Wheat Board scandal and the Children Overboard incident. With agency comes responsibility. As one interviewee argued, where policy failure does occur (provided that responsibility for failure can be attributed), public servants should be held to account.

\title{
Conclusion
}

This chapter has investigated a practitioner-academic study of federal environment policy episodes using Marsh and McConnell's framework for understanding policy success. My analysis demonstrates the absence of public policy theory in the tool kit of the 51 policymakers interviewed. Additional studies are needed to test the universality or uniqueness of this finding, and the implications of the disconnect between policy theory and practice. 
This research, based on rare access to the inner workings of federal environment policymaking, unearthed multilayered descriptions of how officials go about their tasks in environment policy. The insights revealed by the officials have implications for the deepening of public policy theory. In particular, policy thinking would do well to be more inclusive of the intentions and strategies — the 'agency' — of officials, including their vital roles in attempting to steer policy away from failure towards success, drawing on their practical insights and collaborative practices to secure small and large policy wins.

My study found that policy officials were able to deliver policy successes even in the absence of a coherent policy theory or framework. Nevertheless, training in the art and craft of policy is essential. It is more efficient to train new policy graduates in what is known (lessons and good practices), rather than relying on the time-honoured APS practice of throwing graduates into the deep end of policy work. This chapter suggests the need for a focus on how a deeper study of practice can inform theory, which in turn can be used to assist in the training of practitioners, rather than focus on how current policy theory can enhance the work of policy practitioners.

These findings suggest that, for public policy theory to gain greater relevance, we could do well to focus on the tactical manner in which officials pursue policy agendas. These findings remind policy practitioners that their skills and interventions (or absence of action) are vital in the policy process, notwithstanding contemporary pressures towards politicisation and marginalisation of the public service. Further analysis in other policy areas (e.g. employment, education, health, tax reform and aged care) would test the wider relevance of these findings. The increasing turbulence and politicisation of the policy process make it all the more imperative for policy theories to assist in training officials in the art of evidence-based, compelling policy advice that can 'stick', and for officials to focus on providing sound policy advice that puts the long-term interests of all Australians above narrow and short-term vested interests.

Major policy problems facing the nation, from the treatment of Indigenous and displaced peoples to the impacts of climate change, require that policy practitioners need access to rapid support services to help them provide compelling and defensible options to decision-makers. It is important to build 'communities of practice' in which the policy client, the people who design and deliver policy, and those who seek to understand policy, can all work together. 
In summary, policymakers learn on-the-job, not from theory; the agency of policymakers warrants more attention in theory; and practical experience (or 'dirty hands') make for better policy. In informing participants in the big debates on stability and change, policy officials have a critical role in presenting options and likely consequences to ministers. Public policy theorists and educators have an important role in arming the policy practitioners with the best knowledge kit possible. Persistence, courage and knowing where to draw the line between advocacy and advice are increasingly necessary tools in that kit.

\section{References}

Allen, P \& Wanna, J 2016, 'Developing leadership and building executive capacity in the Australian public services for better governance', in A Podger \& J Wanna (eds), Sharpening the sword of state: Building executive capacities in the public services of the Asia-Pacific, ANU Press, Canberra, ACT, doi.org/ 10.22459/SSS.11.2016.02.

Australian National Audit Office 2010, Home insulation program, audit report no. 12, ANAO, Canberra, ACT.

Australian Royal Commission into the Home Insulation Program 2014, Report of the Royal Commission into the home insulation program, Government of Australia, Canberra, ACT.

Banks, G 2013, 'Restoring trust in public policy: What role for the public service?' Garran Oration for the IPAA, 21 November.

Colebatch, HK 2006, 'Thinking about policy: Finding the best way', presentation to Govnet International Conference, 29 November, ANU, Canberra.

Colebatch, H, Hoppe, R \& Noordegraff, M (eds) 2010, Working for policy, Amsterdam University Press, Amsterdam, The Netherlands, doi.org/10.5117/ 9789089642530.

Commonwealth of Australia, Senate, Environment, Communications and the Arts References Committee 2010, Inquiry into the energy efficiency homes package ('ceiling insulation'), Australian Government, Canberra, ACT.

Dryzek, J 1983, 'Don't toss coins in garbage cans: A prologue to policy design', Journal of Public Policy, vol. 3, no. 4, pp. 345-67, doi.org/10.1017/S0143814 $\mathrm{X} 00007510$.

Glyde, P 2019, 'Letter to the editor', Sydney Morning Herald, 24 July. 
Government of South Australia 2019, Report of the Royal Commission on the Murray-Darling basin, Government of South Australia, Adelaide, SA.

Hawke, A 2010, Review of the administration of the home insulation program, Australian Government, Canberra, ACT.

Intergovernmental Panel on Climate Change 2018, Global warming of $1.5^{\circ} \mathrm{C}$, special report, viewed 31 January 2020, www.ipcc.ch/sr15/.

Kingdon, J 1984, Agendas, alternatives and public policies, Little Brown, Boston, MA.

Kingdon, J 2003, Agendas, alternatives and public policies, 2nd edn, Longman, New York, NY.

Kingdon, J 2011, Agendas, alternatives and public policies, updated 2nd edn, Longman, Boston, MA.

Lindblom, C 1959, 'The science of muddling through', Public Administration Review, vol. 19, no. 3, pp. 79-88, doi.org/10.2307/973677.

Mackie, K 2014, 'Federal environment policymaking in Australia: Avoiding failure; pursuing success', PhD thesis, UNSW.

Mackie, K 2016, 'Success and failure in environment policy: The role of policy officials', Australian Journal of Public Administration, vol. 75, no. 3, pp. 291-304, doi.org/10.1111/1467-8500.12170.

Mackie, K 2018, Succeeding and failing in Australian environmental policy, Brou Lake Publishing, Canberra, ACT.

Marsh, D \& McConnell, A 2010, 'Towards a framework for establishing policy success', Public Administration, vol. 88, no. 2, pp. 564-83, doi.org/10.1111/ j.1467-9299.2009.01803.x.

Samnakay, N 2017, 'Thinking strategically in federal policy: Defining the attributes of high-level policies', Australian Journal of Public Administration, vol. 76, no. 1, pp. 106-21, doi.org/10.1111/1467-8500.12199.

Towell, N 2013, 'Challenges in a changing world', Canberra Times, 27 July.

Williams, A 2010, 'Is evidence-based policymaking really possible? Reflections for policymakers and academics on making use of research in the work of policy', in H Colebatch, R Hoppe \& M Noordegraff (eds), Working for policy, Amsterdam University Press, Amsterdam, The Netherlands, doi.org/ 10.1515/9789048513086-016. 
This text is taken from Learning Policy, Doing Policy: Interactions Between Public Policy Theory, Practice and Teaching, edited by Trish Mercer, Russell Ayres, Brian Head and John Wanna, published 2021 by ANU Press, The Australian National University, Canberra, Australia.

$$
\text { doi.org/10.22459/LPDP.2021.09 }
$$

